\title{
JBIR-25, a novel antioxidative agent from Hyphomycetes sp. CR28109
}

\author{
Keiichiro Motohashi ${ }^{1}$, Yasuhiro Gyobu ${ }^{2}$, Motoki Takagi ${ }^{1}$ and Kazuo Shin-ya ${ }^{3}$
}

The Journal of Antibiotics (2009) 62, 703-704; doi:10.1038/ja.2009.96; published online 16 October 2009

Keywords: antioxidative agent; Hyphomycetes; JBIR-25; radical scavenging

Active oxygen species cause many diseases such as atherosclerosis, inflammation, ischemia-reperfusion injury, rheumatoid arthritis and central nervous diseases. ${ }^{1}$ Further, senility and cancer initiation as well as progression are also believed to involve active oxygen species. ${ }^{2}$ Thus, it is expected that effective antioxidative agents may prevent the onset and development of these diseases. In the course of our screening program of novel antioxidants, we isolated a novel antioxidative agent, designated as JBIR-25 (1), from the culture of Hyphomycetes sp. CR28109. This paper describes the isolation, structural elucidation and briefly the biological activity of $\mathbf{1}$ (Figure 1).

Hyphomycetes sp. CR28109 was isolated from a soil sample collected in Ashigara, Kanagawa Prefecture, Japan, and cultured at $25^{\circ} \mathrm{C}$ for 14 days in a 500-ml Erlenmeyer flask containing $80 \mathrm{~g}$ brown rice and $2 \mathrm{~g}$ oatmeal in static culture. The culture was extracted with $80 \%$ aq. $\mathrm{Me}_{2} \mathrm{CO}(100 \mathrm{ml})$. After concentration in vacuo, the aqueous concentrate was extracted with EtOAc (three times). The organic layer was dried over $\mathrm{Na}_{2} \mathrm{SO}_{4}$ and evaporated to dryness. The residue $(0.51 \mathrm{~g})$ was applied to normal-phase medium pressure liquid chromatography (Purif-Pack SI-60, Moritex, Tokyo, Japan) and eluted with a gradient system of $n$-hexane-EtOAc $(0-30 \% \mathrm{EtOAc})$ and $\mathrm{CHCl}_{3}-\mathrm{MeOH}$ $(0-50 \% \mathrm{MeOH})$, successively. The $5 \% \mathrm{MeOH}$ elute fraction $(25.5 \mathrm{mg})$ was further purified by the preparative reversed-phase HPLC using a PEGASIL ODS column (Senshu Pak, 20 i.d. $\times 150 \mathrm{~mm}$, Senshu Scientific, Tokyo, Japan) with $50 \% \mathrm{MeOH}-\mathrm{H}_{2} \mathrm{O}$ containing $0.1 \%$ formic acid (flow rate: $10 \mathrm{ml} \mathrm{min}^{-1}$ ) to yield $\mathbf{1}(13.5 \mathrm{mg}$, Retention time (Rt), $10.5 \mathrm{~min}$ ).

Compound $\mathbf{1}$ was isolated as a colorless oil that gave a $[\mathrm{M}+\mathrm{H}]^{+}$ion at $\mathrm{m} / \mathrm{z} 477.1504$ in the high-resolution electrospray ionization-MS consistent with a molecular formula of $\mathrm{C}_{22} \mathrm{H}_{24} \mathrm{~N}_{2} \mathrm{O}_{10}$ (calculated for $\left.\mathrm{C}_{22} \mathrm{H}_{25} \mathrm{~N}_{2} \mathrm{O}_{10}, 477.1509\right)$, and displayed the UV and IR spectra as follows; UV (MeOH) $\lambda_{\max }(\varepsilon) 278$ (2460) and 219 (13 140); IR (KBr) $v_{\max } 3430$ and $1720 \mathrm{~cm}^{-1}$.<smiles>O=C(COC(=O)C(Cc1ccc(O)cc1)=NO)C(O)=NOCC(O)Cc1ccc(O)cc1</smiles><smiles>CC(C)(C)O[14C@@H](COC(=O)/C(Cc1ccc(O)cc1)=N/O)[14CH2]OC(=O)/C(Cc1ccc(O)cc1)=N/O</smiles>

Figure 1 Structures of JBIR-25 (1) and 11,11'-acetonide JBIR-25 (2).

The ${ }^{1} \mathrm{H}$ and ${ }^{13} \mathrm{C}$ NMR spectral data for $\mathbf{1}$ are shown in Table 1 . The completely symmetrical carbon signals were observed, indicating that $\mathbf{1}$ is a symmetric compound. The structural information on $\mathbf{1}$ was further obtained by the series of two-dimensional NMR analyses such as heteronuclear single quantum coherence (HSQC), heteronuclear multiple-bond correlation (HMBC) and double quantum filtered correlation (DQF-COSY) spectra (Figure 2). $\mathrm{A}^{1} \mathrm{H}^{-}{ }^{1} \mathrm{H}$ spin correlation was observed between doublet aromatic protons $1 / 5-\mathrm{H}\left(\delta_{\mathrm{H}} 7.09\right)$ and $2 / 4-\mathrm{H}\left(\delta_{\mathrm{H}} 6.65\right)$. In the HMBC spectrum, $2 / 4-\mathrm{H}$ were strongly $m$-coupled to each other and coupled to an aromatic quaternary carbon C-6 $\left(\delta_{\mathrm{C}} 127.3\right)$. Further, $1 / 5-\mathrm{H}$ were also strongly $m$-coupled to each other, and coupled to an aromatic carbon C-3 $\left(\delta_{\mathrm{C}} 155.8\right)$ and a methylene carbon C-7 $\left(\delta_{\mathrm{C}} 29.2\right)$ in the HMBC spectrum. A singlet

${ }^{1}$ Biomedicinal Information Research Center (BIRC), Japan Biological Informatics Consortium (JBIC), Koto-ku, Tokyo, Japan; ${ }^{2}$ Bioscience Labs, Meiji Seika Kaisha, Odawara-shi, Kanagawa, Japan and ${ }^{3}$ Biomedicinal Information Research Center (BIRC), National Institute of Advanced Industrial Science and Technology (AIST), Koto-ku, Tokyo, Japan Correspondence: Dr M Takagi, Biomedicinal Information Research Center (BIRC), Japan Biological Informatics Consortium (JBIC), 2-42 Aomi, Koto-ku, Tokyo 135-0064, Japan. E-mail: motoki-takagi@aist.go.jp or Dr K Shin-ya, Biomedicinal Information Research Center (BIRC), National Institute of Advanced Industrial Science and Technology (AIST), 2-42 Aomi, Koto-ku, Tokyo 135-0064, Japan.

E-mail: k-shinya@aist.go.jp

Received 15 June 2009; revised 1 September 2009; accepted 24 September 2009; published online 16 October 2009 
Table $1{ }^{1} \mathrm{H}$ and ${ }^{13} \mathrm{C}$ NMR data for 1 and 2

\begin{tabular}{|c|c|c|c|c|}
\hline \multirow[b]{2}{*}{ No. } & \multicolumn{2}{|r|}{1} & \multicolumn{2}{|r|}{2} \\
\hline & ${ }^{13} \mathrm{C}$ & ${ }^{1} \mathrm{H}(\mathrm{J}$ in $\mathrm{Hz})$ & ${ }^{13} \mathrm{C}$ & ${ }^{1} \mathrm{H}(\mathrm{J}$ in $\mathrm{Hz})$ \\
\hline $1,1^{\prime}$ & 130.0 & $7.09, d(8.3)$ & 130.2 & $7.05, d(8.3)$ \\
\hline $2,2^{\prime}$ & 115.0 & $6.65, d(8.3)$ & 115.3 & $6.65, d(8.3)$ \\
\hline $3,3^{\prime}$ & 155.8 & & 157.0 & \\
\hline $4,4^{\prime}$ & 115.0 & $6.65, d(8.3)$ & 115.3 & $6.65, d(8.3)$ \\
\hline $5,5^{\prime}$ & 130.0 & $7.09, d(8.3)$ & 130.2 & $7.05, d(8.3)$ \\
\hline $6,6^{\prime}$ & 127.3 & & 128.5 & \\
\hline $7,7^{\prime}$ & 29.2 & $3.84, \mathrm{~s}$ & 30.3 & $3.81, \mathrm{~s}$ \\
\hline $8,8^{\prime}$ & 151.4 & & 152.3 & \\
\hline $9,9^{\prime}$ & 164.2 & & 165.0 & \\
\hline $10,10^{\prime}$ & 66.9 & $\begin{array}{l}\text { 4.40, dd }(12.2,4.3) \\
4.23 \text {, dd }(12.2,11.4)\end{array}$ & 61.5 & $\begin{array}{l}3.68, \mathrm{dd}(11.5,5.0) \\
3.61, \mathrm{dd}(11.5,6.5)\end{array}$ \\
\hline $11,11^{\prime}$ & 69.5 & $3.76, \mathrm{~m}$ & 78.8 & $4.22, \mathrm{~m}$ \\
\hline 12 & & & 25.5 & $1.33, \mathrm{~s}$ \\
\hline 13 & & & 28.2 & $1.42, \mathrm{~s}$ \\
\hline
\end{tabular}

${ }^{13} \mathrm{C}(125 \mathrm{MHz})$ and ${ }^{1} \mathrm{H}(500 \mathrm{MHz}) \mathrm{NMR}$ spectra were taken on a NMR system $500 \mathrm{NB} \mathrm{CL}$ (Varian, Palo Alto, $\mathrm{CA}, \mathrm{USA}$ ) in $\mathrm{CD}_{3} \mathrm{OD}$, and the solvent peak was used as an internal standard $\left(\delta_{\mathrm{C}} 49.0, \delta_{\mathrm{H}} 3.30\right)$.

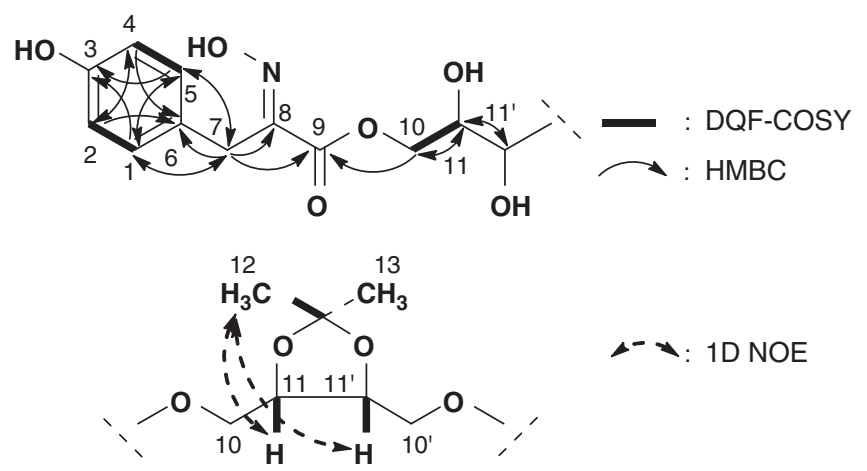

Figure 2 Key correlations in DQF-COSY (bold line) and HMBC (arrow) spectra of $\mathbf{1}$, and 1D NOE correlations obtained from 2.

methylene proton $7-\mathrm{H}\left(\delta_{\mathrm{H}} 3.84\right)$ was long-range coupled to aromatic methine carbons $\mathrm{C}-1 / 5\left(\delta_{\mathrm{C}} 130.0\right)$ and C-6. Thus, the methylene carbon C-7 was deduced to be substituted at the position of C-6. All the assignments of this disubstituted benzene ring moiety were established by ${ }^{1} \mathrm{H}-{ }^{13} \mathrm{C}$ long-range couplings, as shown in Figure 2. In addition, the ${ }^{1} \mathrm{H}-{ }^{13} \mathrm{C}$ long-range couplings from a methylene proton 7-H to an ester carbonyl carbon $\mathrm{C}-9\left(\delta_{\mathrm{C}} 164.2\right)$ and an imino carbon C-8 $\left(\delta_{\mathrm{C}} 151.4\right)$ and from methylene proton $10-\mathrm{H}\left(\delta_{\mathrm{H}} 4.40,4.23\right)$ to $\mathrm{C}-9$ revealed a 3-(4-hydroxyphenyl)-2-iminopropanoate moiety. A ${ }^{1} \mathrm{H}-{ }^{1} \mathrm{H}$ spin coupling in DQF-COSY spectrum was observed between oximethine proton $11-\mathrm{H}\left(\delta_{\mathrm{H}} 3.76, \delta_{\mathrm{C}} 69.5\right)$ and $10-\mathrm{H}$. Finally, 11-H was long-range coupled to an oximethine carbon $\mathrm{C}-11^{\prime}\left(\delta_{\mathrm{C}}\right.$ 69.5), which is exactly the own carbon signal in the $\mathrm{HMBC}$ spectrum, indicating that $\mathbf{1}$ consisted of a symmetric structure at C-11, as shown in Figure 1. From the molecular formula of 1, four hydroxyl groups were determined to be substituted at the position of C-3, C-3', C-11 and C-11', and remaining two hydroxyl groups were assigned to oxime functional groups at the imino moieties C- 8 and C- $8^{\prime}$. The geometries of the C-8 and $\mathrm{C}-8^{\prime}$ at oxime moieties were elucidated as $E$ from the upfield ${ }^{13} \mathrm{C}$ chemical shift of C-7 and C-7' $\left(\delta_{\mathrm{C}} 29.2\right)$ due to the $\gamma$-effect of hydroxyl group in the oxime function. The difference in ${ }^{13} \mathrm{C}$ chemical shifts between $E\left(\delta_{\mathrm{C}} \quad 27.5\right)$ and $Z\left(\delta_{\mathrm{C}} 35.7\right)$ was observed in $(E, Z)-N, N^{\prime}$-bis (3-(3'-bromo-4'-hydroxyphenyl)-2-oximidopropionyl) cystamine ${ }^{3}$ the positions of which corresponded to C-7 and C-7' in 1 . This result supported the stereochemistry at $\mathrm{C}-8$ and $\mathrm{C}-8^{\prime}$. The relative configurations of $\mathrm{C}-11$ and $\mathrm{C}-11^{\prime}$ were established by preparation of its five-membered 11,11'-acetonide ring that was subjected to $1 \mathrm{D} \mathrm{NOE}$ experiment, as shown in Figure 2. Compound $1(1.0 \mathrm{mg})$ was dissolved in $0.2 \mathrm{ml}$ of acetone, to which $0.1 \mathrm{ml}$ of 2,2-dimethoxypropane and $0.8 \mathrm{mg}$ of $p$-toluene sulfonate were added, and stirred at room temperature for $2 \mathrm{~h}$ to give 2 . The reaction mixture was then concentrated to dryness, and the residue was dissolved with $10 \mathrm{ml}$ of $\mathrm{CHCl}_{3}$. The $\mathrm{CHCl}_{3}$ solution was washed twice with $5 \mathrm{ml}$ of $5 \% \mathrm{NaHCO}_{3}$ solution and then twice with $5 \mathrm{ml}$ of $\mathrm{H}_{2} \mathrm{O}(\mathrm{pH} 7)$. The organic layer was dried over $\mathrm{Na}_{2} \mathrm{SO}_{4}$ and concentrated in vacuo. The oily residue was purified by an L-column2 ODS column (20 i.d. $\times 150 \mathrm{~mm}$; Chemical Evaluation and Research Institute, Tokyo, Japan) with $60 \% \mathrm{MeOH}-\mathrm{H}_{2} \mathrm{O}$ (flow rate: $10 \mathrm{ml} \mathrm{min}^{-1}$ ) to yield 11,11'-acetonide JBIR-25 (2) (0.72 mg; Rt, $10.8 \mathrm{~min})$. The assignments of ${ }^{1} \mathrm{H}$ and ${ }^{13} \mathrm{C}$ NMR data of 2 were determined by HSQC experiment, as shown in Table 1. The 1D NOE correlation of 2 was observed only between a singlet methyl proton $12-\mathrm{H}\left(\delta_{\mathrm{H}} 1.33\right)$ and oxymethine protons $11-\mathrm{H}$ and/or $11^{\prime}-\mathrm{H}\left(\delta_{\mathrm{H}} 4.22\right)$. On the basis of this data, the relative configuration of 1 was concluded to be $11 R^{\star}$ and $11^{\prime} S^{\star}$, as shown in Figure 1. Moreover, the optical rotation value of $1\left([\alpha]_{D}^{25} 0^{\circ}(c 1.0, \mathrm{MeOH})\right.$ indicated that 1 is the mixture of enantiomers at the ratio of 1:1. The monomeric structure of 1 was found to be structurally related to phenylpyruvic acid oxime isolated from a marine sponge, Psammaplysilla purpurea. ${ }^{4}$ However, the symmetric structure such as that of $\mathbf{1}$ produced by a fungus is the first example.

We evaluated the 1,1-diphenyl-2-picrylhydrazyl (DPPH) radical scavenging activity of 1 . A 96-well plate was used for the DPPH radical scavenging assay. ${ }^{5}$ Compound 1 and $\alpha$-tocopherol as a positive control were dissolved in $\mathrm{MeOH}$ as the stock solution (1 mM). In total, $90 \mu \mathrm{l}$ of $200 \mu \mathrm{M} \mathrm{DPPH}$ dissolved in $\mathrm{MeOH}$ and $10 \mu \mathrm{l}$ of sample were mixed in the microplate. After $1 \mathrm{~h}$ incubation at room temperature, the absorbance was measured at $540 \mathrm{~nm}$. Compound 1 showed DPPH radical scavenging activity with an $\mathrm{IC}_{50}$ value of $79 \mu \mathrm{M}$, which was almost the same activity as that of $\alpha$-tocopherol $\left(\mathrm{IC}_{50}=50 \mu \mathrm{M}\right)$.

\section{ACKNOWLEDGEMENTS}

This work was supported by a grant from the New Energy and Industrial Technology Department Organization (NEDO) of Japan.

1 Hammond, B., Kontos, H. A. \& Hess, M. L. Oxygen radicals in the adult respiratory distress syndrome, in myocardial ischemia and reperfusion injury, and in cerebral vascular damage. Can. J. Physiol. Pharmacol. 63, 173-187 (1985).

2 Finkel, T. Radical medicine: treating ageing to cure disease. Nat. Rev. Mol. Cell. Biol. 6, 971-976 (2005).

3 Arabshahi, L. \& Schmitz, F. J. Brominated tyrosine metabolites from an unidentified sponge. J. Org. Chem. 52, 3584-3586 (1987).

4 Yagi, H., Matsunaga, S. \& Fusetani, N. Purpuramines A-I, new bromotyrosine-derived metabolites from the marine sponge Psammaplysilla purpurea. Tetrahedron 49, 3749-3754 (1993).

5 Izumikawa, M., Nagai, A., Doi, T., Takagi, M. \& Shin-ya, K. JBIR-12, a novel antioxidative agent from Penicillium sp. NBRC 103941. J. Antibiot. 62, 177-180 (2009). 